\title{
Physiographic-Tectonic Zoning of Iran's Sedimentary Basins
}

\author{
Mehran Arian \\ Department of Geology, Science and Research Branch, Islamic Azad University, Tehran, Iran \\ Email: mehranarian@yahoo.com
}

Received December 19, 2012; revised January 28, 2013; accepted February 18, 2013

Copyright (c) 2013 Mehran Arian. This is an open access article distributed under the Creative Commons Attribution License, which permits unrestricted use, distribution, and reproduction in any medium, provided the original work is properly cited.

\begin{abstract}
Base on geological history evaluation using regional stratigraphy, sedimentary environments, magmatic activities, metamorphism and structural trend in Iran, physiographic-tectonic zoning map of Iran's sedimentary basins has prepared. This map has prepared to point out the basement tectonics role in Iran. It contains twenty-four different provinces. Iran has composed from different plates: Arabian plate in south and west, Cimmerian manipulated in north and east, Eurasian plate in northeast margin. Cimmerian manipulated at least can be divided to the smaller part, East-Central Iran and North-Central Iran microcontinents. There are evidences for thick-skinned tectonics in the border zones of these plates and microcontinents, especially in Sanandaj-Sirjan overthrust belts that it formed by crustal stacking wedges. Also, Neoproterozoic-Phanerozoic Tectonic column in the Arabian, Cimmerian and Eurasian plates under Iran Country area have introduced.
\end{abstract}

Keywords: Physiographic; Tectonics; Plate; Iran; Microcontinents; Basin

\section{Introduction}

The organization and development of the physiographictectonic provinces of Iran involves specifying the current structural geomorphology and tectonic history of Iran's sedimentary basins that might have clear effect in the regions. A physiographic-tectonic province is a geological unit that it has a same history since sedimentation time to recent. Each physiographic-tectonic province has a same structural trend and dominant mechanism of deformation, because these have related to tectonic settings, magmatic histories, stratigraphic variations and deformational models of crust. So, physiographic-tectonic provinces can bind others. In this study, regional tectonics [1] and geological data have integrated in together for preparation of the physiographic-tectonic zoning map of Iran's sedimentary basins. The main steps in this study have summarized as follows:

1) Geological data such as regional stratigraphy, sedimentary environments, magmatic activities, metamorphism, tectonic stages and deformational styles that provided much information on the tectonic history have gathered from different references; 2) Physiographic-tectonic zoning map of Iran's sedimentary basins based on sedimentary basins position has identified. These basins described by some researchers [2-4]; 3) Structural units have lim- ited for each individual physiographic-tectonic province based on different works such as [5-8]; 4) Tectonic units have limited for each individual identified plate and microcontinents (Figure 1) based on $[9,10]$.

\section{Structural Zoning of Iran}

At the first time, a geologist [5] has provided structural history and tectonics for Iran and then, geology of Iran has compiled by [2]. Investigation in geology of Iran shows there are many different structural units. Iran is one of the most deformed areas of the Alpine-Himalayan orogenic belt.

The structural provinces of Iran have studied by several researchers but in this study, a new Physiographictectonic zoning map of sedimentary basins (Figure 2) base on updated data has proposed. The boundaries of the provinces have established through considering of geological materials, structural styles, tectonic settings, major faults and physiographic divisions.

\section{Physiographic-Tectonic Provinces}

\subsection{Zagros-East Taurus Hinterland}

Dominant structural trends in Zagros province (Figure 2) are NW-SE in northwestern part and E-W in southeastern 


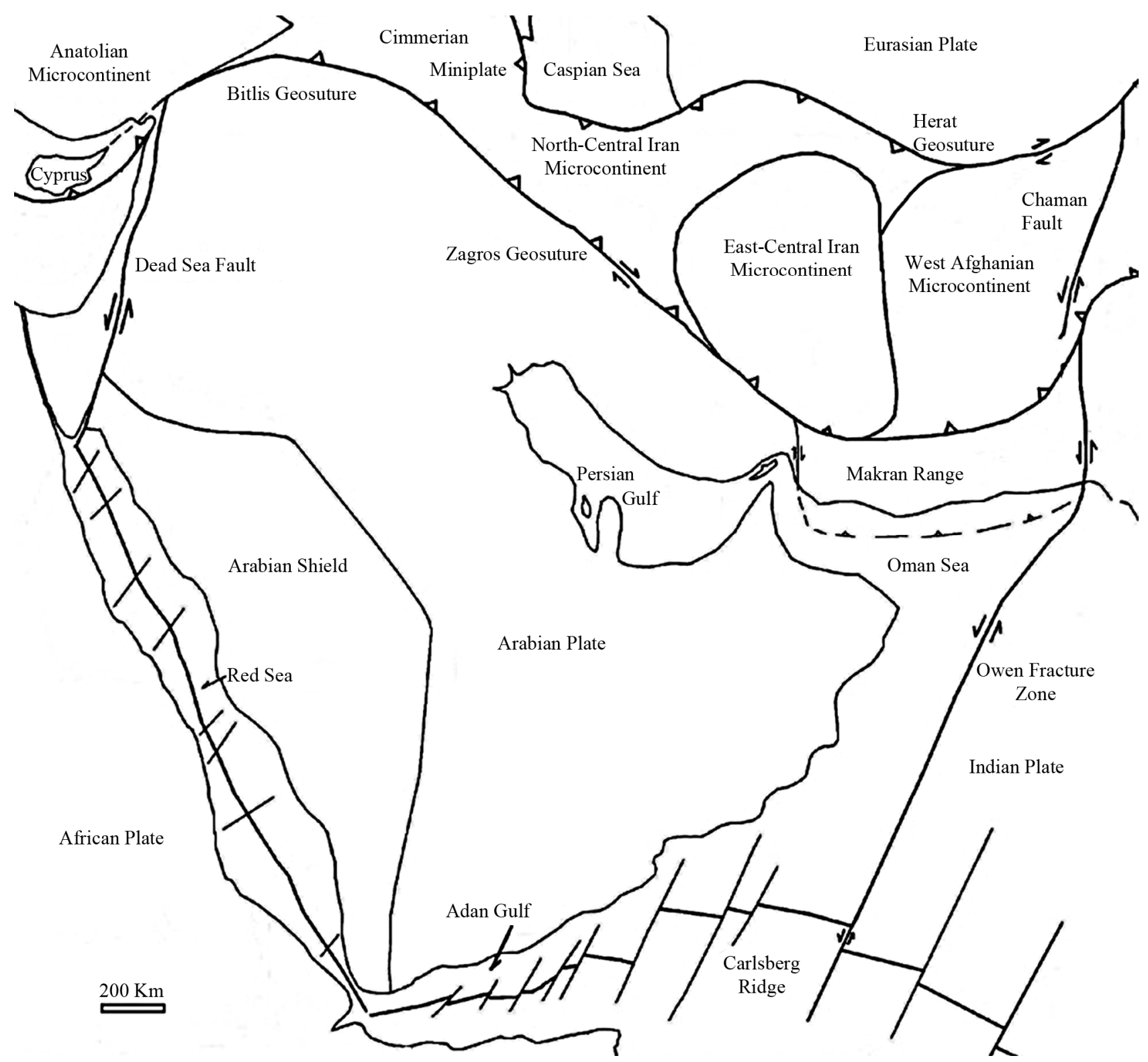

Figure 1. Tectonic framework map of Iran in Middle East.

part. From tectonics view, it contains the overthrust and simple fold belts of Zagros that formed on the northeastern part of Arabian plate's passive margin (Figure 1).

Zagros Mountains have continued to East Taurus Mountains in Turkey and have named Zagros-East Taurus hinterland. Zagros-East Taurus hinterland is external platform (fold and thrust belt) of north margin of Arabian Craton (Figure 1). Vergence of folding in this hinterland is toward south and southwest.

\subsection{Persian Gulf-Mesopotamian Foreland Basin}

Dominant structural trend in Persian Gulf foreland basin province (Figure 2) is NW-SE. From tectonics view, it contains the south margin of simple fold belts of Zagros that formed on the northeastern part of Arabian plate's passive margin. Persian Gulf has continued to end of Mesopotamian area in central Iraq and have named Persian Gulf-Mesopotamian foreland basin. Persian GulfMesopotamian foreland basin is north margin of internal platform of north margin of Arabian craton (Figure 1).

\subsection{Makran Accretionary Prism}

Dominant structural trend in Makran province (Figure 2) is E-W. From tectonics view, it contains the accretionary prism on trench of Oman sea subduction that has continued to Pakistan (Figure 1). Makran accretionary prism has 150 (Iran) to 350 (Pakistan) Km width that its north 


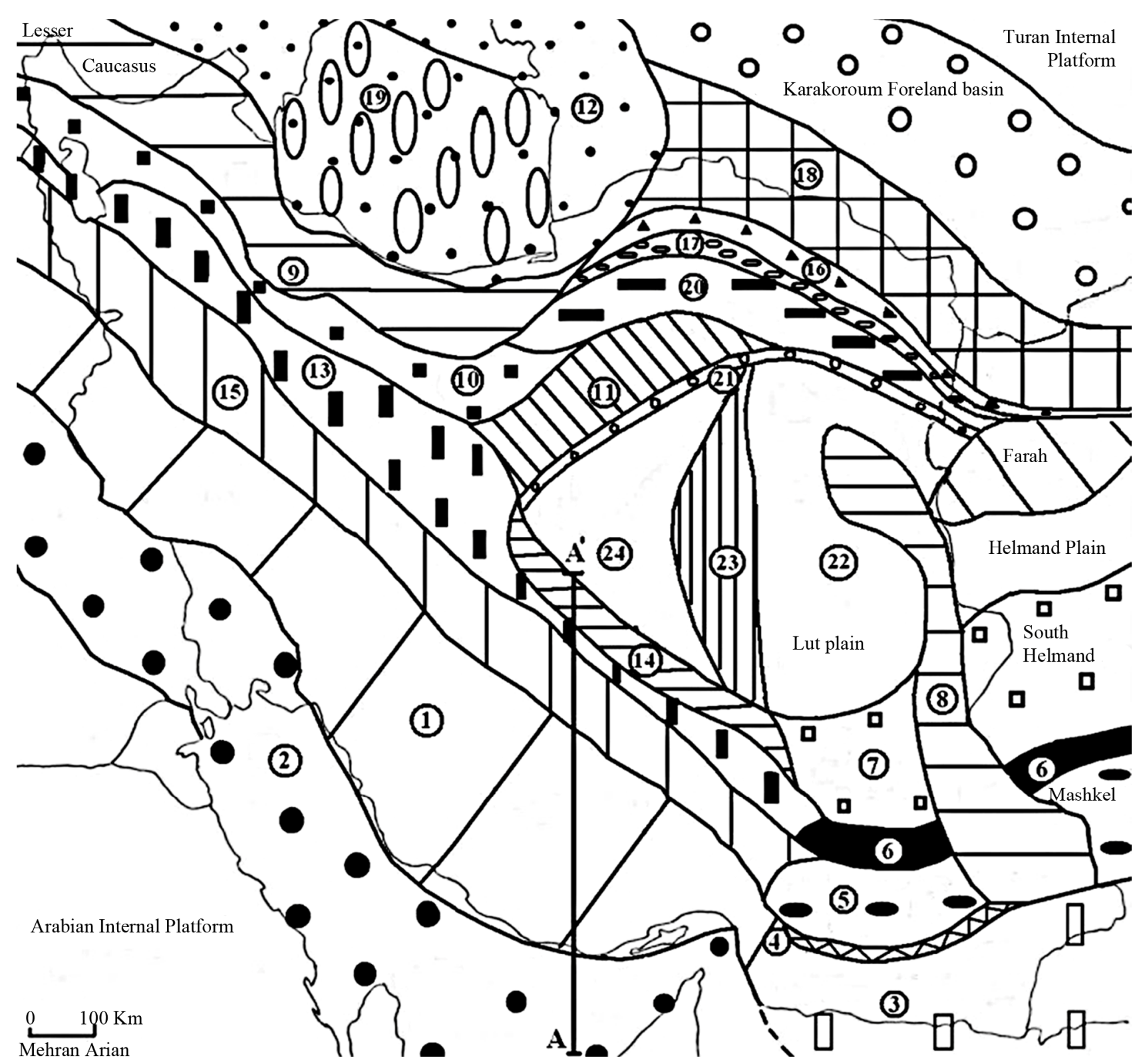

Figure 2. Physiographic-tectonic zoning map of Iran's sedimentary basins Iran. Numbers in this figure are, 1: Zagros-East Taurus hinterland, 2: Persian Gulf-Mesopotamian foreland basin, 3: Makran accretionary prism, 4: Bashagard Mountains, 5: Jazmorian-Mashkel fore arc basin, 6: Shahsavaran-Soltan magmatic arc, 7: South Lut-South Helmand back arc basin, 8: East Iran Mountain belt, 9: West-Central Alborz and lesser Caucasus hinterland, 10: Great Kavir-Northen Urmieh lake foreland basin, 11: South Great Kavir fold and thrust belt, 12: South Caspian-Black sea foreland basin, 13: Urmieh-Dokhtar Magmatic Arc, 14: Naien-Kerman retro arc foreland basin, 15: Sanandaj-Sirjan overthrust belts, 16: East Alborz or Binalod hinterland, 17: Torbat-e am-Neyshabour retro arc foreland basin, 18: Kopet Dagh hinterland, 19: South Caspian remnant basin, 20: Maiamay-Taibad Inverted back arc basin, 21: Khaf-Kavir Plain Magmatic Arc, 22: Lut Plain-Gonabad back arc basin, 23: Tabas hinterland, 24: Yazd-Khour Piggy back basin.

part uplifted and formed Makran range.

\subsection{Bashagard Mountains}

Dominant structural trend in Bashagard province (Figure 2) is E-W. From tectonics view, it contains upper slope part of Makran accretionary prism that has terminated to East Iran Mountain belt (Figure 2). Bashagard province is a sign for bending zone of Arabian oceanic lithosphere.

\subsection{Jazmorian-Mashkel fore Arc Basin}

Dominant structural trend in Jazmorian province (Figure 2) is E-W. From tectonics view, it contains a fore arc basin (Jazmorian plain) that has continued to Mashkel 
plain in Pakistan (Figure 2). Jazmorian-Mashkel fore arc basin has formed on south margin of East-Central Iran microcontinent and filled by Paleogene Turbidities and Neogene-Quaternary terrestrial sediments. Note that low seismicity in Makran and Jazmorian provinces has related to slow subduction rate and steeper dip of Benioff zone. Current subduction rate of oceanic crust (related to late Cretaceous) is 19 millimeters per year [11].

\subsection{Shahsavaran-Soltan Magmatic Arc}

Dominant structural trend in Shahsavaran-Soltan province (Figure 2) is E-W. From tectonics view, it contains an active magmatic arc that has continued to northeast in Pakistan. Shahsavaran-Soltan magmatic arc has formed on south margin of East-Central Iran microcontinent and it contains 16 Quaternary eruptive centers with $450 \mathrm{~km}$ length.

\subsection{South Lut-Helmand Back Arc Basin}

Dominant structural trend in South Lut province (Figure 2) is E-W. From tectonics view, it contains a retro arc back arc basin that has continued to Helmand plain in Pakistan. South Lut-Helmand back arc basin has formed on south part of East-Central Iran microcontinent and it contains $2 \mathrm{Km}$ Tertiary volcanic rocks eruptive centers with $450 \mathrm{~km}$ length.

\subsection{East Iran Mountain Belt}

Dominant structural trend in East Iran province (Figure 2) is N-S. From tectonics view, it contains the magmatic arc and its accretionary prism belt that is result of westward subduction of west Afghanistan microcontinent (Figure 1) beneath to East-Central Iran microcontinent.

Therefore, East Iran province has named Sistan or East Iran suture zone too. Recently, a dextral transpression zone (Nehbandan fault system) has developed on the eastern border of this province that it marked by horsetail splays on the northern and southern terminations (Figure 2).

\subsection{West-Central Alborz and Lesser Caucasus Hinterland}

Dominant structural trend in West-Central Alborz and lesser Caucasus province (Figure 2) is NW-SE. From tectonics view, it contains deformed zone (fold and thrust belt) of Cimmerian miniplate (Figure 1) that formed in northern active margin until late Triassic. Then it has rifted by tension in a back arc basin of Neotethyian subduction zone in the south margin of Cimmerian miniplate. Development of that rift stopped in the late Cretaceous and then, renewed in the Eocene by spreading in submarine arc basin of Neotethyian subduction zone. In the other word, this hinterland is result of a magmatic arc system [12] spreading in the evolutional back arc basin. After that, West-Central Alborz and lesser Caucasus hinterland has formed by deformation and regional uplift from SW part of Caspian Sea to Black sea.

Recently, Damavand and Sebalan cones have formed by late volcanism that related to final subduction of oceanic slab in south Caspian basin toward south and southwest. Five dominant orogenic phases and four deformational events in Alborz Mountain building processes have suggested by [13].

The first deformational event is one from the Syn-collision type between Cimmerian and Eurasian plates (late Triassic) and the other ones are from post-collision deformational events and in with the deformational of sedimentary cover which is result of shortening and increasing the thickness of passive continental crust in north of Cimmerian miniplate.

\subsection{Great Kavir-Northern Urmieh Lake Foreland Basin}

Dominant structural trend in Great Kavir-Northern Urmieh lake province (Figure 2) is NW-SE. From tectonics view, it contains the southern foreland basin of WestCentral Alborz and lesser Caucasus hinterland in the north margin of Cimmerian miniplate (Figure 1) since late Eocene.

Also, this foreland basin in Pishva (Varamin) is a piggyback basin that formed on thrust sheets. In Tehran area, this basin is a deformed basin [14] by active thrusting in footwall of North Tehran fault.

\subsection{South Great Kavir Fold and Thrust Belt}

Dominant structural trend in South Great Kavir fold and thrust belt province (Figure 2) is NE-SW. From tectonics view, it contains fold and thrust belt that formed on the south margin of North-Central Iran microcontinent (Figure 1). This belt have deformed by collision of NW part of East-Central Iran microcontinent with North-Central Iran microcontinent, on the passive margin setting. South Great Kavir fold and thrust belt is a peneplain like area by extensive erosion.

\subsection{South Caspian-Black Sea Foreland Basin}

Dominant structural trend in South Caspian-Black sea foreland basin province (Figure 2) is NW-SE. From tectonics view, it contains the northern foreland basin of West-Central Alborz and lesser Caucasus hinterland in the south margin of Eurasian plate (Figure 1) since late Eocene. Although, median part of South Caspian and Black sea basin has uplifted by collision between Eurasian and Cimmerian plates. 


\subsection{Urmieh-Dokhtar Magmatic Arc}

Dominant structural trend in Urmieh-Dokhtar province (Figure 2) is NW-SE. From tectonics view, it contains a magmatic arc that is result of subduction to beneath of southern active continental margin of Cimmerian plate. Also, Sahand and other cones (about 9) in lesser Caucasus hinterland are result of quaternary magmatism in this zone that it has marked by widespread Eocene volcanism. Urmieh-Dokhtar province has continued to south of Black Sea and Its width has increased from Naien city that many parts have covered by quaternary deposits of Dagh Sorkh Kavir, Southern Urmieh Lake, Namak and Hoz-e Soltan Lakes have formed on it. So, there are a few backland basins with Playa type sedimentation because of dip decreasing in Ben off zone (in NW part of magmatic arc). SE part of magmatic arc has formed on southwest margin of East-Central Iran microcontinent.

\subsection{Naien-Kerman Retro Arc Foreland Basin}

Dominant structural trend in Naien-Kerman province (Figure 2) is NW-SE. From tectonics view, it contains a retro arc foreland basin on the north margin of UrmiehDokhtar magmatic arc (SE part). Davaran Mountain and Bafgh-Baghin fault system [15] have developed in this province that formed on southwest part of East-Central Iran microcontinent.

\subsection{Sanandaj-Sirjan Overthrust Belts}

Dominant structural trend in Sanandaj-Sirjan province (Figure 2) is NW-SE. From tectonics view, it contains Sanandaj-Sirjan overthrust belts that formed by metamorphic rocks of the northeastern part of Arabian plate [8]. This province has continued to the north part of Dead Sea fault in the south Turkey. Late Cretaceous-Paleogene sequences in this belt have piled up on a wedge top part [16] of Zagros proforeland basin [17], before regional metamorphism. Recently, pre-Cretaceous deformed and metamorphic rocks have exposed in this province by upthrusting of basement wedges (Figure 3).

Quaternary basins such as southern margin of Urmieh Lake, Kabodarahang depression, Mighan Kavir, Gavkhoni depression, Abarkuh Kavir, Marvast Kavir and Sirjan's Kavir-e Namak, on the north boundary of this province with Urmieh-Dokhtar are the index cases from Supra-Arc troughs. These basins are significant in marking loss of the fore-arc basin beneath back-thrusts antithetic to the subduction direction and can explain the presence of younger molasse in a setting referred to as a suture zone [19].

\subsection{East Alborz or Binalod Hinterland}

Dominant structural trend in East Alborz province (Fig-

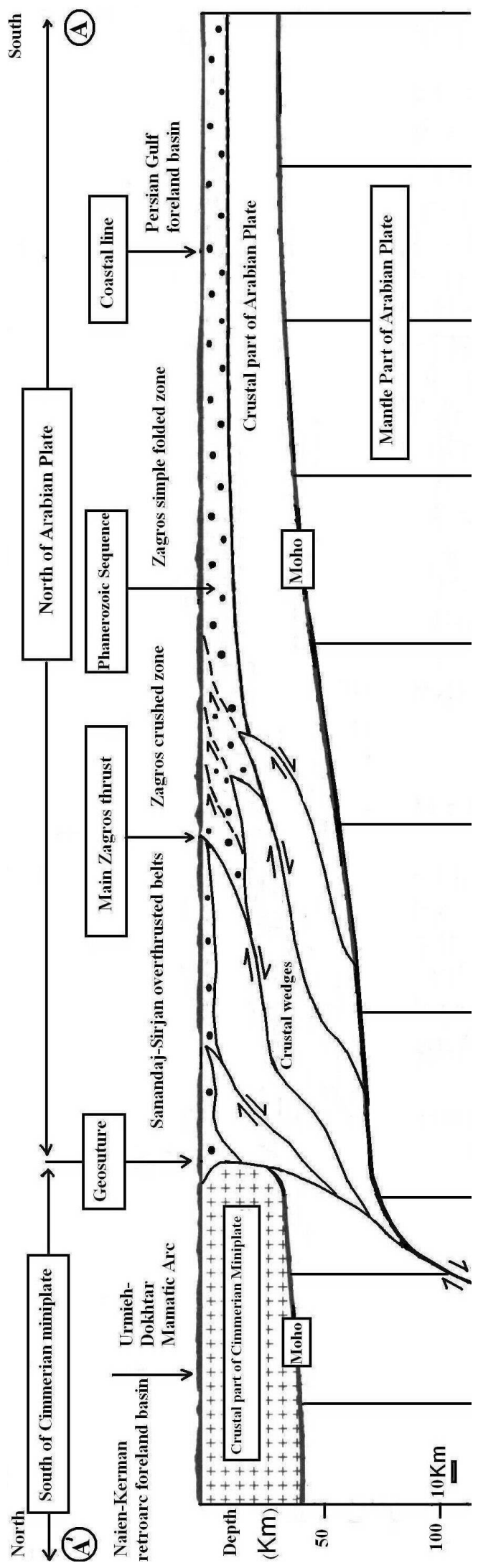

Figure 3. A deep north-south cross section from south Iran (AA' in Figure 2), modified from [18]. 
ure 2) is NW-SE in eastern part and NE-SW in western part. From tectonics view, it contains Binalod magmatic arc and its fore arc basin with volcanic activities (especially in Silurian) on northeastern of Cimmerian miniplate. Obduction of Mashhad ophiolite during late Paleozoic has result of subduction into beneath this province (Figure 4) but marine sedimentation on Kopet Dagh proforeland basin (Over thinned crust of south Eurasian plate) has continued to Eocene. Also, East Alborz fore arc basin gradually uplifted and it has formed a hinterland with SW vergence.

\subsection{Torbat-e Jam-Neyshabour Retroarc Foreland Basin}

Dominant structural trend in Torbat-e Jam-Neyshabour province (Figure 2) is NW-SE in eastern part and NE$\mathrm{SW}$ in western part. From tectonics view, it contains the Torbat-e Jam-Neyshabour retro arc foreland basin on northeastern part of North-Central Iran microcontinent.

A magmatic arc has formed on north and parallels to this province that it has underthrusted beneath East Alborz province since Paleogene. Torbat-e Jam-Neyshabour retro arc foreland basin has filled by erosion of that magmatic arc.

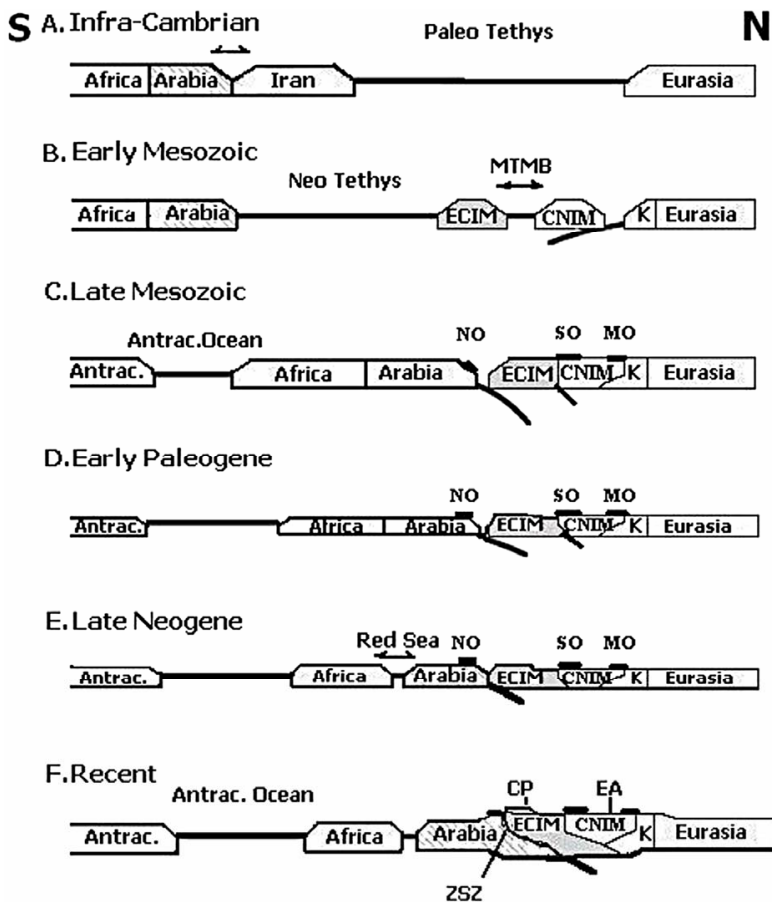

Figure 4. Tectonic history of Iran. Abbreviations in this figure are, ECIM: East-Central Iran microcontinent, CNIM: Central-North Iran microcontinent, EA: East Alborz, MTMB: Maiamay-Taibad marginal back arc basin, K: Kopet Dagh, CP: Central Iran collision plateau, ZSZ: Zagros Suture Zone, MO: Mashhad Ophiolite, MO: Mashhad Ophiolite, SO: Sabzevar Ophiolite, NO: Neyriz Ophiolite. Position of these cross sections has drawn on Figure 5.

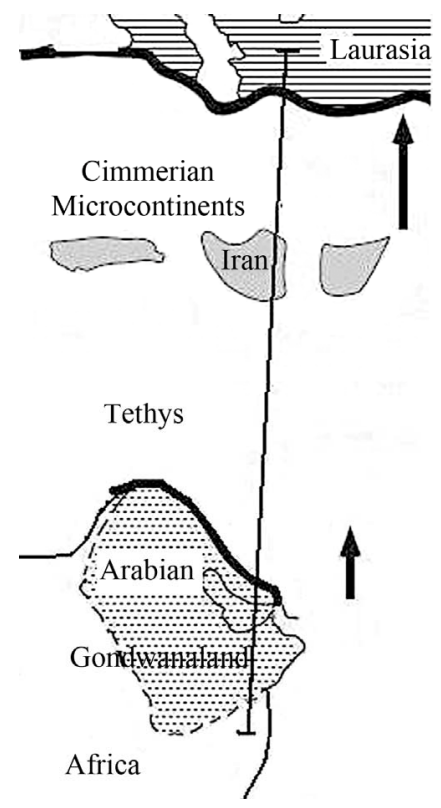

Figure 5. Sketch map of Iran and surrounding area during late Paleozoic. Position of Figure 4 cross sections has drawn by straight line. Bold lines show continental passive margins, modified from [20].

\subsection{Kopet Dagh Hinterland}

Dominant structural trend in Kopet Dagh province (Figure 2) is NW-SE. From tectonics view, it contains the Kopet Dagh hinterland or Kopet Dagh fold and thrust belt that formed in passive margin of Eurasian plate until late Triassic and then marine sedimentation on Kopet Dagh proforeland basin has continued to Eocene.

Kopet Dagh hinterland has uplifted related to Karakorum foreland basin in northeast along Eshghabad fault.

\subsection{South Caspian Remnant Basin}

Dominant structural trend in South Caspian province (Figure 2) is NW-SE in eastern part and N-S in western part. From tectonics view, it contains the South Caspian remnant oceanic basin [21] and northern foreland basin of Central Alborz hinterland.

Therefore it is a hybrid basin over an old island arc that it has formed by southward Paleotethyan intraoceanic subduction. This province is subducting beneath to Apsheron-Sill ridge [22] on north boundary of South Caspian now [23].

\subsection{Maiamay-Taibad Inverted Back Arc Basin}

Dominant structural trend in Great Kavir-Taibad province (Figure 2) is NW-SE in eastern part and NE-SW in western part. From tectonics view, it contains the Maiamay-Taibad marginal back arc basin with Sabezevar Ophiolites and Torbat-e Heydarieh volcanic rocks that inverted in paleogene. 


\subsection{Khaf-Kavir Plain Magmatic Arc}

Dominant structural trend in Khaf-Bardeskan province (Figure 2) is NW-SE in the eastern part and NE-SW in the western part. From tectonics view, it contains the northern active margin of East-Central Iran microcontinent (Figure 1). It has formed by southward subduction of oceanic lithosphere (under Maiamay-Taibad marginal back arc basin) that named Sabzevar Ocean [24].

\subsection{Lut Plain-Gonabad Back Arc Basin}

Lut Plain-Gonabad back arc basin on the Lut microcontinent (eastern portion of East-Central microcontinent) has placed on the west of East Iran Mountain belt.

Dominant structural trend in East-Central Iran province (Figure 2) is N-S. From tectonics view, it contains back arc (retro arc) basin that it has related to westward subduction of west Afghanistan microcontinent beneath to East-Central Iran microcontinent. Recently, horsetail splays in northern termination of Nehbandan fault system have developed in the northern part of this province.

\subsection{Tabas Hinterland}

Dominant structural trend in East-Central Iran province (Figure 2) is N-S. From tectonics view, it contains an ancient island arc on the west of the Lut Plain-Gonabad province that it has accreted to this along Nayband fault system (western border of the Lut microcontinent) by eastward subduction in Pre-Cambrian.

\subsection{Yazd-Khour Piggy Back Basin}

Dominant structural trend in East-Central Iran province (Figure 2) is N-S. From tectonics view, it contains a few ancient island arcs [25] that they have accreted together by eastward subductions [6].

\section{Tectonic Column of Iran}

Iran has composed from different plates: Arabian plate in south and west, Cimmerian manipulated in north and east, Eurasian plate in northeast margin.

\subsection{Arabian Plate}

\subsubsection{Zagros Orogen}

Neoproterozoic-Phanerozoic Tectonic column in Zagros province under Iran country area (Figure 2) are at least contain 5 tectonic stages between 4 below events:

1) Compressive event of late proterozoic (Pan African orogeny); 2) Tensional event of Infra-Cambrian; 3) Tensional event of Triassic; 4) Compressive event of Neogene (Zagrosian orogeny). Two above tensional events are related to regional rifting that it occurred next to the Gondwana drift. In global scale, they are approximately equivalent to movements of Caledonian and Hercynian orogenies, but in this period the Zagros basin have been formed a broad passive margin on the northeastern part of Afro-Arabian plate (Figure 6).

\subsubsection{Persian Gulf Basin}

Neoproterozoic-Phanerozoic Tectonic column in Persian Gulf foreland basin province (Figure 2) are at least contain 4 tectonic stages between 3 below events:

1) Compressive event of late proterozoic (Pan African orogeny); 2) Tensional event of Infra-Cambrian; 3) Tensional event of Triassic.

Compressive event of Neogene (Zagrosian orogeny) has not recorded in this province until recent. Similar to

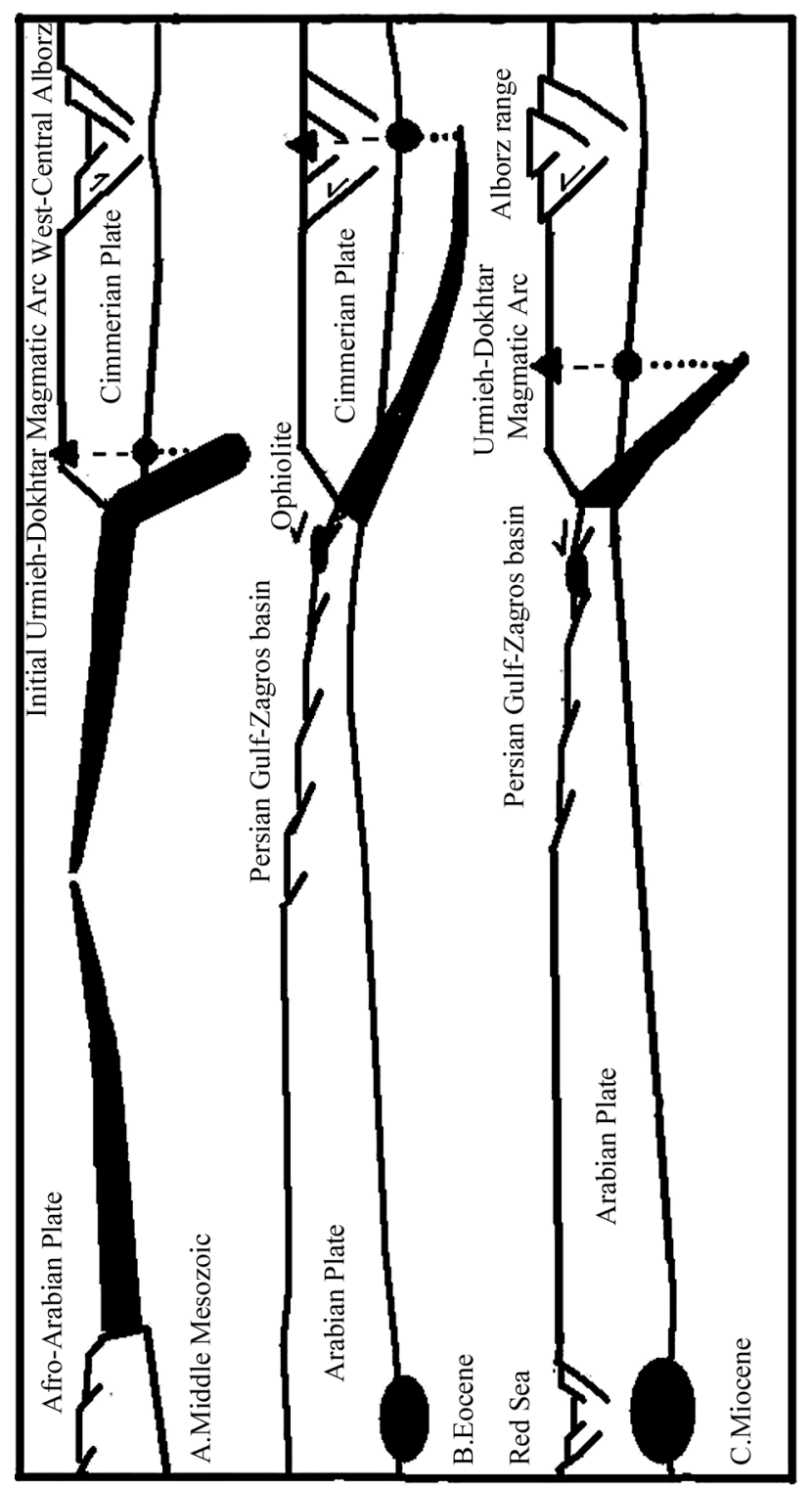

Figure 6. Tectonic position of Persian Gulf and Zagros basins on the Arabian plate and some basins on the Cimmerian plate. 
the Zagros province, two above tensional events are related to regional rifting that it marked by some sedimentary gaps such as Carboniferous sequences.

\subsection{Cimmerian Miniplate}

Neoproterozoic-Phanerozoic Tectonic column in Cimmerian miniplate under Iran country area (Figure 1) are at least contain 8 tectonic stages between 7 below events:

1) Compressive event of late proterozoic (Pan African orogeny); 2) Tensional event of Infra-Cambrian-Late Paleozoic (equivalent to movements of Caledonian and Hercynian orogenies) that it has marked by some sedimentary gaps such as in lower Paleozoic and Carboniferous sequences on the Alborz basin; 3) Compressive event of late Triassic (Early Cimmerian orogeny); 4) Tensional event of Late Jurassic; 5) Compressive event of Late early Alpine orogeny; 6) Tensional event of the Middle Alpine orogeny; 7) Compressive event of the Late Alpine orogeny.

Two later tensional events are related to back arc spreading (Figure 6) that it has been inverted by consequence compressive events.

\subsection{Eurasian Plate}

Neoproterozoic-Phanerozoic Tectonic column in Eurasian plate under Iran country area (Figure 1) are at least contain 5 tectonic stages between 4 below events:

1) Compressive event of late proterozoic (Cadomian orogeny); 2) Compressive event of Late Paleozoic (Hercynian orogeny); 3) Compressive event of late Triassic (Early Cimmerian orogeny); 4) Compressive event of the Late Alpine orogeny.

\section{Discussion}

Geological history evaluation using regional stratigraphy, sedimentary environments, magmatic activities, metamorphism and structural trend in Iran are showing that it contains twenty four different provinces.

There are much evidence for three main continentcontinent collision such as magmatic arcs, ophiolitic sequences, orogenic belts and them foreland basins. The first one is along northern boundary of Binalod (16) and West-Central Alborz and lesser Caucasus (9) provinces that it known as Paleotethyan suture zone.

The second continent-continent collision zone is along northern boundary of Sanandaj-Sirjan province (15) that it known as Neotethyan suture zone and it has formed on the top of the crustal stacking wedges. The third continent-continent collision zone is along eastern boundary of Lut Plain-Gonabad province (22) that it known as mezotethyan suture zone. Base on gravimetric survey of Iran [26], all of them have thick-skinned tectonics.
Also, there are some evidence for an ocean-continent covergence such as Makran accretionary prism (province No. 3), Jazmorian-Mashkel fore arc basin, (province No. 5), Shahsavaran-Soltan magmatic arc (province No. 6), South Lut-South Helmand back arc basin (province No. 7).

The Paleotethyan and Neotethyan suture zones have same orientations (NW-SE) from median part of Iran toward west and so, four different mountain ranges have formed.

They are the most parts of Zagros-East Taurus hinterland with deformed sedimentary rocks (province No. 1), West-Central Alborz and lesser Caucasus hinterland with deformed volcano-sedimentary rocks (province No. 9), Urmieh-Dokhtar Magmatic Arc (province No. 13) and Sanandaj-Sirjan overthrust belt with deformed metamorphic rocks (province No. 15).

These have formed a broad mountain chain with more than $1200 \mathrm{~km}$ length and $400 \mathrm{~km}$ width from the southern part of Caspian sea to Black sea. Four above mountains have different ages, basements, structural styles and rocks, thus it seem that they can consider as Iranian Cordillera.

\section{Conclusions}

Physiographic-tectonic zoning map of Iran's sedimentary basins has prepared to indicate basement tectonics role in Iran. Characteristic of this zoning map are as follows:

The map has intended as a pattern for the assessment of the structural trends in Iran.

- Cimmerian miniplate at least can be divided to the smaller part, East-Central Iran and North-Central Iran microcontinents.

- Zagros and Alborz hinterlands and border zones of East-Central Iran microcontinent have thick-skinned tectonics.

- Sanandaj-Sirjan province has formed on the crustal stacking wedges of Arabian plate.

- East Alborz orogeny is the oldest mountain building Iran.

- Tectonic events of Paleozoic (equivalent to movements of Caledonian and Hercynian orogenies) in the most part of Iran have a tensional role and they have marked by long sedimentary gaps.

- Paleozoic sedimentary gaps are related to block faulting in rifted region.

- Iran country has composed from four mountain ranges that they can consider as Iranian Cordillera.

\section{Acknowledgements}

This work has funded by the Department of geology, Islamic Azad University, Science and Research branch, Tehran, Iran. Also, Special thanks to vice-president for research in Science and Research branch, Tehran. 


\section{REFERENCES}

[1] M. Qorashi and M. Arian, “Tectonics of Iran,” Geologic Survey of Iran, Tehran, 2011, 336p. (In Persian)

[2] M. H. Nabavi, “An Introduction to Geology of Iran,” Geologic Survey of Iran, Tehran, 1976, 109p. (In Persian)

[3] J. Eftekharnezhad, "Division of Different Part of Iran Base on Structural Position in Related to Sedimentary Basins," Journal of Iranian Petroleum Association, Vol. 82, No. 1, 1980, pp. 19-28. (In Persian)

[4] S. A. Aghanabati, “Geology of Iran,” Geologic Survey of Iran, Tehran, 2001, 586p. (In Persian)

[5] J. Stocklin, "Structural History and Tectonics of Iran: A Review,” AAPG Bulletin, Vol. 52, No. 7, 1968, pp. 12291258.

[6] M. Berberian, "Structural Evolution of the Iranian Plateau," Contribution to the Seismotectonics of Iran (Part IV), Report No. 52, Geologic Survey of Iran, Tehran, 1981, pp. 19-66.

[7] M. A. A. Nogole Sadat, “Tectonic Map of Iran,” Treatise on the Geology of Iran, Geologic Survey of Iran, Tehran, 1993

[8] M. Alavi, “Tectonics of the Zagros Orogenic Belt of Iran: New Date and Interpretations,” Tectonophysics, Vol. 229, No. 3-4, 1994, pp. 211-238.

[9] M. Alavi, “Tectonic map of the Middle East, 1:5000000,” Geologic Survey of Iran, Tehran, 1991.

[10] M. Arian, "Basement Tectonics and Geology of Iran," Asar Nafis Press, Qum, 2011, 300p. (In Persian)

[11] P. Vernant, F. Nilforoushan, D. Hatzfeld, M. R. Abbasi, C. Vigny, F. Masson, H. Nankali, J. Martinod, A. Ashtiani, R. Bayer, F. Tavakoli and J. Chery, "Present-Day crustal Deformation and Plate Kinematics in the Middle East Constrained by GPS Measurements in Iran and Northern Oman," Geophysical Journal International, Vol. 157, No. 1, 2004, pp. 381-398.

[12] M. Alavi, "Tectonostratigraphic Synthesis and Structural Style of the Alborz Mountain System in Northern Iran," Journal of Geodynamics, Vol. 21, No. 1, 1996, pp. 1-33.

[13] M. Arian, Z. Maleki and H. Noroozpour, "Cenozoic Diastrophism and Deformational Events in the East-Central Alborz," Journal of Basic and Applied Scientific Research, Vol. 1, No. 11, 2011, pp. 2394-2400.

[14] A. D. Miall, “Collision-Related Foreland Basins,” In: C. J. Busby and R. V. Ingersoll, Eds., Tectonics of Sedimentary Basins, Blackwell Science, Oxford, 1995, pp. 393-424.

[15] M. Arian, M. Pourkermani, A. Sistanipour and H. Norooz- pour, "Kinematic Significance of Fold- and Fault-Related Fracture Systems in the Rafsanjan's Northeast Highlands (Central Iran)," Journal of Basic and Applied Scientific Research, Vol. 1, No. 12, 2011, pp. 3398-3406.

[16] P. G. De Celles and K. A. Giles, "Foreland Basin System,” Basin Research, Vol. 8, No. 2, 1996, pp. 105-123. doi:10.1046/j.1365-2117.1996.01491.x

[17] M. Alavi, "Regional Stratigraphy of the Zagros Fold and Thrust Belt of Iran and Its Proforeland Evolution," American Journal of Science, Vol. 304, No. 1, 2004, pp. 1-20.

[18] P. Giese, J. Makris, B. Akashe, P. Roewer, H. Letz and M. M. Mostaanpour, "Seismic Crustal Studies in Southern Iran between the Central Zagros Belt,” Geologic Survey of Iran, Vol. 1, No. 51, 1983, pp. 71-89.

[19] A. H. G. Mitchell and H. G. Reading, "Sedimentation and Tectonics,” In: H. G. Reading, Ed., Sedimentary Environments and Facies, Blackwell Scientific Publications, Oxford, 1986, pp. 471-519.

[20] J. J. W. Rogers and M. Santosh, "Continents and Supercontinents,” Oxford University Press, Inc., Oxford, 2006, 289p.

[21] M. Berberian, "Southern Caspian: A Compressional Depression Floored by a Trapped, Modified Oceanic Crust," Canadian Journal of Earth Sciences, Vol. 20, No. 2, 1983, pp. 163-183. doi:10.1139/e83-015

[22] J. A. Jackson, K. Priestley, M. Allen and M. Berberian, "Active Tectonics of the South Caspian Basin," Geophysical Journal International, Vol. 148, No. 2, 2002, pp. 214-245.

[23] M. L. Allen, J. Jackson and R. Walker, "Late Cenozoic Reorganization of the Arabia-Eurasia Collision and the Comparison of Short-Term and Long-Term Deformation Rates,” Tectonics, Vol. 23, No. 2, 2004, Article ID: TC 2008.

[24] A. M. C. Sengor, “A New Model for the Late PalaezoicMesozoic Tectonic Evolution of Iran and Implication for Oman,” In: A. H. F. Robertson, M. P. Searle and A. C. Ries, Eds., The Geology and Tectonics of the Oman Region, No. 46, Geological Society Special Publications, London, 1990, pp. 797-831.

[25] J. Stocklin, "Structural Correlation of the Alpine Ranges between Iran and Central Asia,” Société géologique de France, Paris, Mémoire Hors Série, Vol. 1, No. 8, 1977, pp. 333-353.

[26] G. A. Dehghani and J. Makris, "The Gravity Field and Crustal Structure of Iran,” Report No. 51, Geologic Survey of Iran, Tehran, 1983, pp. 51-68. 